\title{
Prevalence of needlestick and sharps injuries in the healthcare workers of Iranian hospitals: an updated meta-analysis
}

\author{
Reza Ghanei Gheshlagh ${ }^{1}$, Marzieh Aslani ${ }^{2}$, Fidan Shabani ${ }^{3}$, Sahar Dalvand ${ }^{4}$ and Naser Parizad ${ }^{5^{*}}$ (D
}

\begin{abstract}
Background: Needlestick and sharps injuries (NSIs) are critical occupational risk among health care workers (HCWs), which is extremely worrying due to the potential risk of transmitting bloodborn pathogens (BBPs). This study was carried out to evaluate the prevalence of NSIs among Iranian HCWs.

Methods: In this systematic review and meta-analysis, the key terms percu* injur*, needle* stick injur*, needlestick* injur*, or sharp* injur* were searched in the Scientific Information Database (SID), Maglran, IranMedex, Google Scholar, Science Direct, PubMed, and Scopus. A prefabricated checklist, including variables: first author, publication year, study population, sample size, gender, total prevalence of needlestick in each gender, type of questionnaire, region, and type of hospitals, was used to extract data from the selected articles included which were published between 2003 and 2016.

Results: The analysis showed that the prevalence of NSIs in the Iranian HCWs was 42.5\% (95\% Cl 37-48). Moreover, the prevalence of NSIs was more in women (47\%; 95\% Cl 36-58) compared to men (42\%; 95\% Cl 26-58).

Conclusion: Given the high prevalence of NSIs, it is necessary to supply safe needles and instruments, hold training programs focused on new methods of using sharp objects safely, observe safety principles and standards, reinforce the practical skills of personnel, and pay more attention to reporting and improving occupational behaviors like avoiding needle recapping in order to reduce the prevalence of NSIs and consequently reduce potential risk of transmission of BBPs.
\end{abstract}

Keywords: Health care workers, Iran, Meta-analysis, Needlestick, Prevalence

\section{Background}

Healthcare workers are at greater risk of occupational exposure to splashes, sharps, and needlestick injuries (SSNIs) [1]. Since, splashing of blood and body secretion has not been mentioned in the majority of studies and their focus was on needlestick and sharp injuries in Iran. Therefore, the researchers investigated NSIs and splashed in the eyes with blood, and body secretions were excluded in this study. Needlestick and sharps injuries are impairments caused by needlestick, a piece of broken ampule, cannula, surgical blade, or other sharp instruments contaminated with blood or body secretions

\footnotetext{
* Correspondence: nparizad@gmail.com

${ }^{5}$ Department of Medical-Surgical Nursing, School of Nursing and Midwifery, Urmia University of Medical Sciences, Pardis Nazlou, $11 \mathrm{~km}$ of Nazlou Road, Urmia, Iran

Full list of author information is available at the end of the article
}

[2]. In 2008, more than 35 million HCWs around the world were exposed to NSIs [3]. In the USA, about 600,000 to 1 million NSIs occur per year, half of them are not reported [4]. Nowadays, NSIs are a serious work-related hazard and a potential risk of transmission of BBPs [5]. Following NSIs, around 20 types of pathogens can be transferred through blood, which is always worrying due to the potential risk of transmission of BBPs [6]. Worldwide, around 40\% of HCWs suffer from hepatitis $\mathrm{B}$ and $\mathrm{C}$ virus infection and $2.5 \%$ are affected by human immunodeficiency virus (HIV) caused by NSIs [7]. These injuries not only raise the possibility of negative health consequences, but also lead to psychological distress, fear, tension, and anxiety in HCWs which results in increasing absence from work and have a direct negative effect on the health care services $[8,9]$. 
On the other hand, medical treatment, blood work, and missed days at work for these injured individuals impose a high cost on the health care system [10]. Although more than $80 \%$ of NSIs can be prevented by observing standard precautions, NSIs are on the rise due to lack of adherence to standard infection control precautions on management and disposal of garbage and clinical waste [11].

Various studies have reported the prevalence of NSIs to be $68 \%$ in Jordan [12], $74 \%$ in South Korea [13], and $30 \%$ in Turkey [14]. Although the reporting of NSIs is important for prevention and treatment, but about 59\% of HCWs do not report their injuries in Iran [15]. The degree of under-reporting of NSIs in HCWs may be as much as ten-fold. Hence, the health care authorities should not interpret this low prevalence rate as less injury in HCWs [16]. This is a very important issue; however, there are few studies conducted to determine prevalence in Iran. Knowing the latest statistics about the prevalence of NSIs could be helpful in designing and implementing programs and guidelines to reduce this national and international health issue. Thus, this systematic review and meta-analysis was conducted to evaluate the prevalence of NSIs in Iranian HCWs and to compare the results with those of national and international studies.

\section{Methods}

\section{Search strategy}

This systematic review and meta-analysis analyzed the prevalence of NSIs among the HCWs (nurses, midwives, doctors, and paramedics) in Iranian hospitals based on the articles published in national and international journals. National databases, (including Scientific Information Database (SID), MagIran, and IranMedex) and international databases, (including Google Scholar, Science Direct, PubMed, and Scopus) were searched to obtain the studies which conducted regarding the prevalence of NSIs. Articles were searched using the key terms percu* injur*, needle* stick injuries*, needlestick injur", sharp* injur*, or Iran as well as all possible combinations of these terms. The Persian sites were also searched using the equivalent of these terms. Further, the sources of studied articles were reviewed to get access to other articles.

\section{Study selection and data extraction}

First, a list of titles and abstracts was prepared from databases by two researchers independently. The inclusion criteria were as follows: (1) observational studies (cross-sectional, case-control, or cohort), (2) articles in Persian and English languages, and (3) methodological quality score $\geq 8$. Qualitative studies, reviews, letters to editor as well as research conducted on students, dentists, and housekeeping staff were excluded from the study. The abstracts of articles were analyzed by two researchers based on the inclusion and exclusion criteria. The relevant articles were selected and their full texts were extracted. Each article was evaluated independently by two researchers. In the case of disagreement on selecting of an article, it was reviewed by a statistician who is an expert in meta-analysis study. A checklist was used to determine the quality of articles. It had been used in different meta-analyses by other researchers $[17,18]$.

This checklist consisted of 12 sections, including objectives, nature of intervention, methods, time period, sample size, sampling method, data collection, outcome variables, study population, cultural and linguistic range, and data analysis. Each section was scored from 0 to 1 , and the range of scores for each article was between 0 and 12 . Thus, articles which scored $\geq 8$ were considered acceptable methodological quality. Moreover, we followed Meline (2006) seven steps recommendations for selecting studies to ensure quality of selected studies. First, we considered inclusion and exclusion criteria for the title and abstract. Secondly, we omitted studies that clearly meet one or more exclusion criteria. In the third step, we obtained the full text of the remaining studies. We evaluated the remaining studies for inclusion and exclusion in the next step. In step five, we included all studies that meet the inclusion criteria, but not exclusion criteria. Then, we excluded studies from study with reasons in the sixth step. Finally, we accepted some studies for our research in the last step [19]. Based on the inclusion and exclusion criteria, 44 qualified articles related to NSIs were selected from 2003 to 2016. Eventually, a prefabricated checklist was used to extract data from the selected articles. The checklist consisted of variables such as the corresponding author, publication year, study population, sample size, gender, the total prevalence of NSIs in each gender, type of questionnaire, region, and type of hospitals. All ethical issues were considered in conducting and reporting of this study.

\section{Statistical analysis}

Since prevalence has binomial distribution, the prevalence variance was calculated by variance of the binomial distribution. Weighted average was used to combine the prevalence rates of various studies, and the weight allocated to every article was the inverse of the variance. Heterogeneity of data was evaluated by $I^{2}$ index and Cochran's $Q$ test. Heterogeneity was classified into the following three categories: $I^{2}$ index $<25 \%$ (low heterogeneity), $I^{2}$ index $=25-75 \%$ (average heterogeneity), and $I^{2}$ index $>75 \%$ (high heterogeneity). Considering the heterogeneity index $\left(I^{2}\right)$ which was more than $75 \%$ (97.6\%), as well as the significance of the Cochran's $Q(p<$ $0.0001)$. Thus, random effects model was used to analyze data in this study. Meta-regression analysis was used to 
evaluate the association between the prevalence of NSIs and publication year and sample size in the selected studies. Also, subgroup analysis was used to assess the prevalence of NSIs for each gender, type of the hospital, instrument, and sampling methods. The role of each study on the final results was investigated using sensitivity analysis. Egger regression asymmetry test was used to evaluate the effects of small studies and publication bias. Data were analyzed by STATA (version 12) software.

\section{Results}

All observational studies carried out on the prevalence of NSIs in Iran were evaluated without time limit and were subjected to systematic review and meta-analysis according to PRISMA guideline [20]. Ninety-nine studies were identified in the initial search. After the title and abstract screening, 28 studies were excluded. Based on the inclusion and exclusion criteria, 27 studies were excluded from the final analysis. A total of 44 articles were included in meta-analysis (Fig. 1).
A total of 44 articles [2, 5, 10, 21-62] were included in meta-analysis. The study sample included 16,105 samples with the mean of 366 samples in each study. The maximum and minimum sample sizes were found in studies conducted by Askarian (1555 samples) [54] and Mohammad Nejad and Hajivandi (each 68 samples) [22, 45]. The general characteristics of the selected studies are presented in Table 1.

The total prevalence of NSIs was $42.5 \%$ (95\% CI $37-48)$ in this study. Since, the studies had been performed on either all HCWs (except students, dentists, and housekeeping staff) of hospitals or exclusively on nurses. Therefore, the prevalence rate was analyzed separately for either nurses or all other health care groups. Findings showed the prevalence of NSIs was more in nurses than in other health care groups $(44 \%$ vs. 41\%). The prevalence of NSIs was reported for each gender separately. Findings showed the prevalence of NSIs was more in women than in men $(47 \%$ vs. $42 \%)[2,10,23,27,28,30,32,36,42,55,56]$.

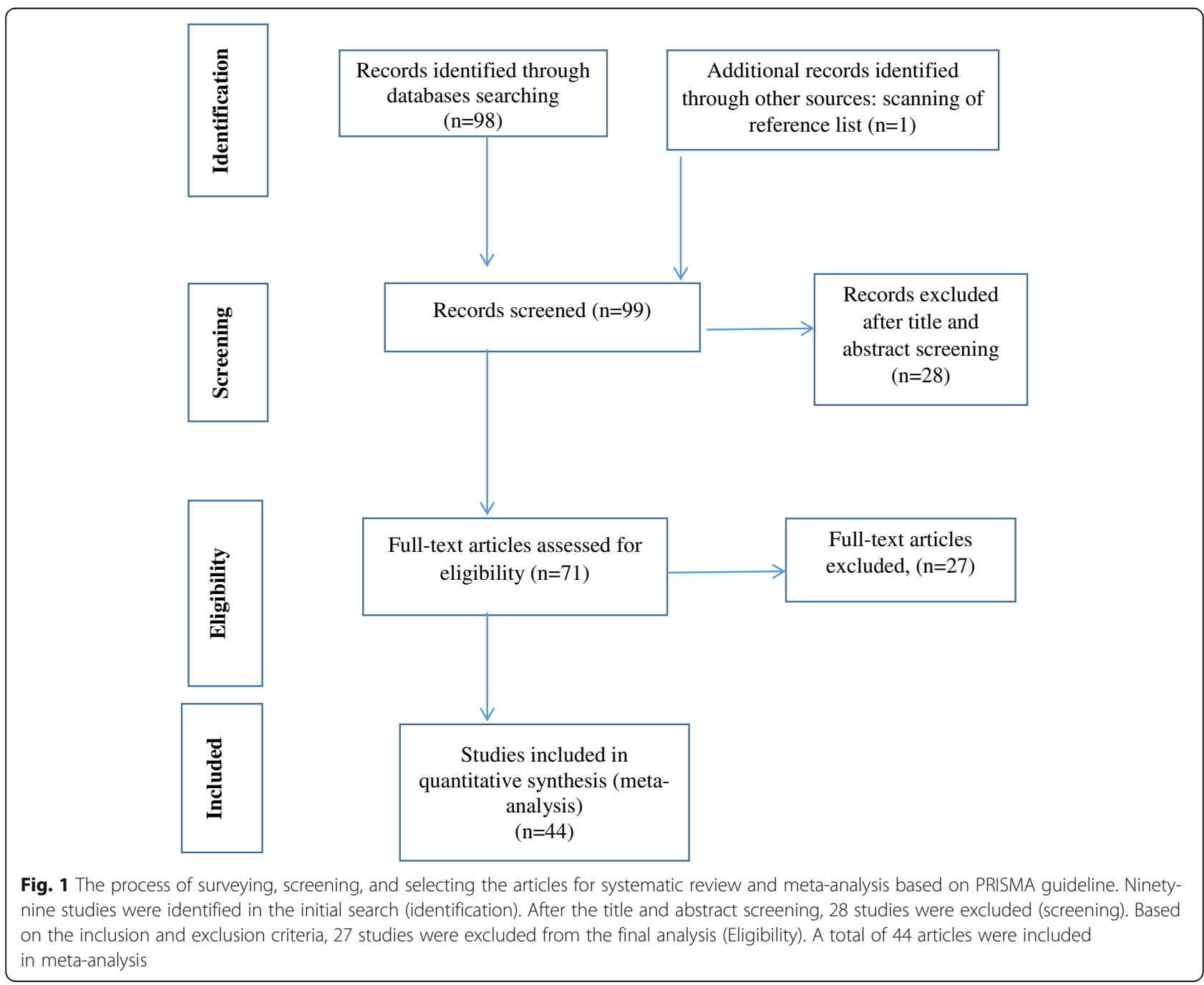


Table 1 Characteristics of selected studies

\begin{tabular}{|c|c|c|c|c|c|c|c|}
\hline \multirow[t]{2}{*}{ First author (references) } & \multirow[t]{2}{*}{ Year } & \multirow{2}{*}{$\begin{array}{l}\text { Sample } \\
\text { size }(n)\end{array}$} & \multirow[t]{2}{*}{ Area } & \multicolumn{2}{|l|}{ Study population } & \multirow{2}{*}{$\begin{array}{l}\text { Type of } \\
\text { hospital }\end{array}$} & \multirow{2}{*}{$\begin{array}{l}\text { Total } \\
\text { prevalence } \\
(\%)\end{array}$} \\
\hline & & & & All healthcare workers & Only nurses & & \\
\hline Geravandi [10] & 2016 & 600 & Ahvaz & * & & Teaching & 8.1 \\
\hline Jahangiri [23] & 2016 & 168 & Shiraz & * & & Teaching & 54 \\
\hline Salman zadeh [25] & 2016 & 377 & Dasht-e Azadegan & * & & Teaching & 18.4 \\
\hline Hajivandi [22] & 2015 & 68 & Bushehr & & * & Teaching & 58.8 \\
\hline Mahmoudi [61] & 2015 & 100 & Tehran & & * & Marital & 41 \\
\hline Izadi [26] & 2015 & 09 & Tehran & * & & Teaching & 26.9 \\
\hline Balouchi [21] & 2015 & 240 & Kerman & & * & Teaching & 39 \\
\hline Mirzaei-Alavijeh [24] & 2014 & 70 & Rafsanjan & & * & Teaching & 41.4 \\
\hline Ghanei Gheshlagh [2] & 2014 & 120 & Saghez & & * & Teaching & 44.2 \\
\hline Bijani [29] & 2013 & 246 & Qazvin & & * & Teaching & 31.3 \\
\hline Adib Hajbaghery [5] & 2013 & 298 & Kashan & * & & Teaching & 38.3 \\
\hline Rezaei [28] & 2013 & 514 & Tehran & & * & Teaching & 26 \\
\hline Shoghli [27] & 2013 & 593 & Zanjan & * & & Teaching & 26.3 \\
\hline Rezaei [32] & 2012 & 991 & Tehran & * & & Teaching & 16.8 \\
\hline Sharifian [31] & 2012 & 350 & Tehran & * & & Teaching & 19.7 \\
\hline Ghannad [35] & 2012 & 89 & Hamadan & * & & Teaching & 51.6 \\
\hline Nejadghaderi [33] & 2012 & 186 & Rafsanjan & * & & Teaching & 54.1 \\
\hline Tirgar [30] & 2012 & 333 & Babol & & * & Teaching & 59.7 \\
\hline Hashemi [34] & 2012 & 700 & Hamadan & * & & Teaching & 24.1 \\
\hline Ehsani [37] & 2012 & 328 & Tehran & & * & Teaching & 45.1 \\
\hline Mohammadi [38] & 2011 & 138 & Qazvin & & * & Teaching & 38.4 \\
\hline Bijani [36] & 2011 & 172 & Qazvin & & * & Teaching & 32 \\
\hline Rahnavard [39] & 2011 & 500 & Rasht & & * & Teaching & 77.2 \\
\hline Shiva [40] & 2011 & 355 & Tehran & * & & Teaching & 49.3 \\
\hline Khalooei [44] & 2010 & 338 & Kerman & & * & Teaching & 33 \\
\hline Nasiri [41] & 2010 & 352 & Sari & * & & Teaching & 75.6 \\
\hline Moradi [46] & 2010 & 182 & Bahar & * & & Teaching & 43.8 \\
\hline Heidari [43] & 2010 & 77 & Borujen & * & & Teaching & 74 \\
\hline Mohammadi Nejad [45] & 2010 & 68 & Tehran & & * & Teaching & 7 \\
\hline Gholami [42] & 2010 & 400 & Urmia & * & & Teaching & 26.8 \\
\hline Kazemi Galougahi [48] & 2010 & 158 & Tehran & & * & Teaching & 57 \\
\hline Mohammad Nejad [50] & 2009 & 218 & Tehran & & * & Teaching & 43.1 \\
\hline Rakhshani [62] & 2009 & 231 & Zahedan & * & & Teaching & 64.9 \\
\hline Abdi [47] & 2009 & 298 & Jahrom & * & & Teaching & 47.3 \\
\hline Joneidi Jafari [51] & 2008 & 613 & Tehran & & * & Marital & 32.7 \\
\hline Lotfi [52] & 2008 & 0 & Astara & * & & Teaching & 7 \\
\hline Azadi [53] & 2007 & 111 & Tehran & & * & Teaching & 45 \\
\hline Askarian [54] & 2007 & 1555 & Shiraz & & * & Teaching & 26.3 \\
\hline Ebrahimi [55] & 2007 & 180 & Shahrud & & * & Teaching & 63.3 \\
\hline Vahedi [57] & 2006 & 847 & Sanandaj & * & & Teaching & 64.9 \\
\hline Nazmieh [59] & 2005 & 1020 & Yazd & * & & Teaching & 37.8 \\
\hline Rahim nejad [56] & 2005 & 434 & Urmia & * & & Teaching & 52.5 \\
\hline Poorolajal [60] & 2004 & 1000 & Hamadan & * & & Teaching & 24 \\
\hline Hoseini Shokouh [58] & 2003 & 88 & Tehran & * & & Marital & 33 \\
\hline
\end{tabular}


Result revealed that the prevalence of NSIs was more in male nurses $(49 \%$; $95 \%$ CI 28-70) compared to men in other health care groups $(37 \%$; $95 \%$ CI $18-$ 56). It was also more in female nurses $(47 \%$; $95 \%$ CI 31-61) compared to women in other health care groups (46\%; 95\% CI 36-58) (Fig. 2).

The prevalence of NSIs for each hospital showed the prevalence rate was more in teaching hospitals than in military hospitals ( $43 \%$ vs. $34 \%$ ). More details on the prevalence ofNSIsforsubgroupsarepresentedin Table2.

The results of meta-regression analysis showed no significant relationship between the prevalence of NSIs and publication year ( $p=0.141$ ( (Fig. 3). However, there was a significant association between the prevalence of NSIs and sample size. The prevalence rate was reduced significantly with a rise in sample size $(p=0.011)$ (Fig. 4).
Further, the findings revealed that publication bias was significant in this study $(p=0.001)$ (Fig. 5). The results of sensitivity analysis indicated that absence of every single study did not make a significant change in frequency estimates. On the other hand, none of the studies had a significant effect individually on estimating the pooled prevalence of NSIs.

\section{Discussion}

Numerous studies on the prevalence of NSIs have reported different results. In spite of all precautions, NSIs are inevitable. This study showed the prevalence of NSIs was $42.5 \%$ in HCWs in Iran, which was higher than the prevalence rate in Turkey (30.1\%) and Qatar (20.9\%) [14, 63] and less than Jordan (91.8\%) and Pakistan (94\%) [64, 65]. Prevalence of NSIs varies depending on hospital

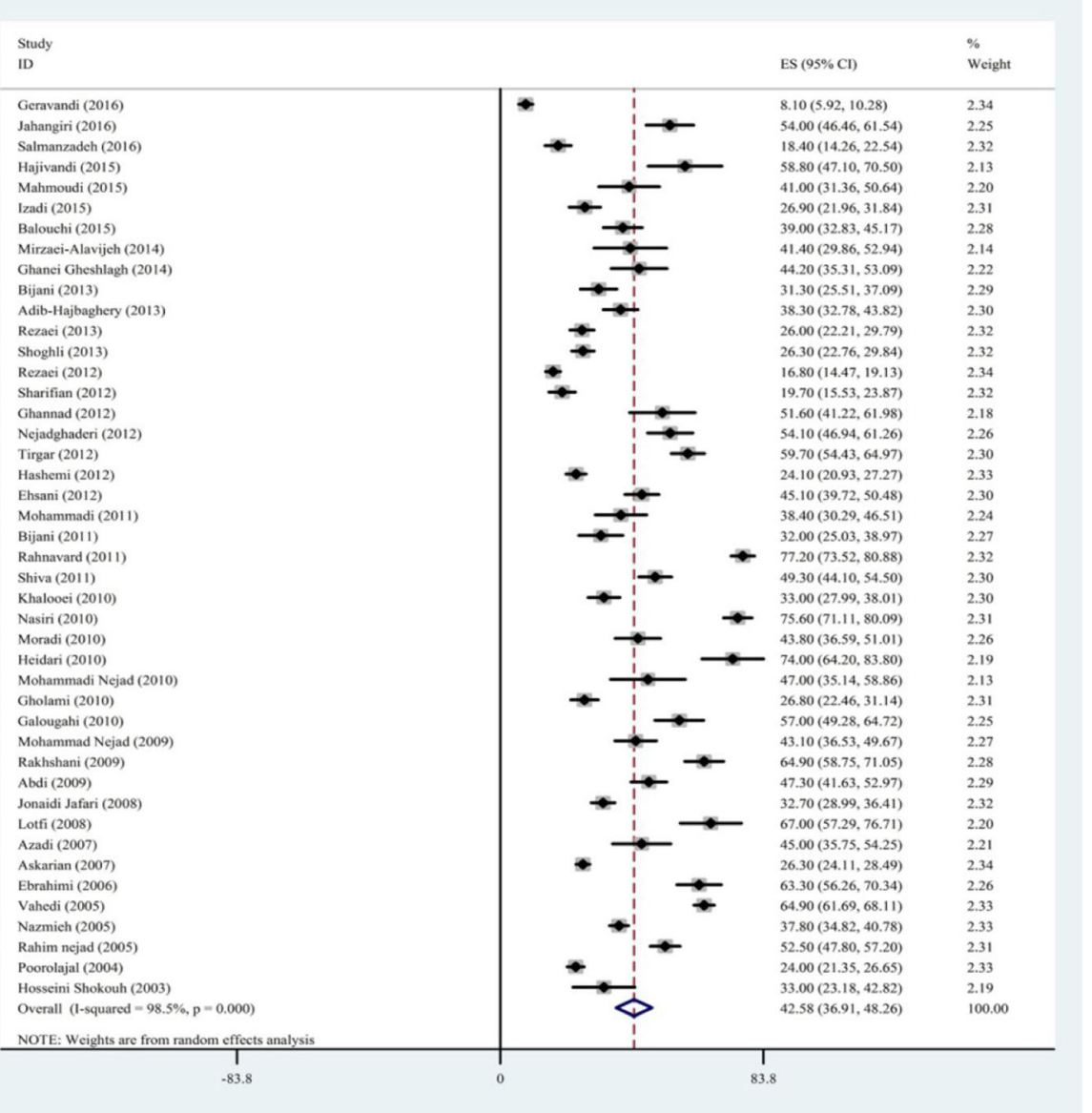

Fig. 2 Prevalence of NSIs in HCWs according to the studies conducted in Iran. This figure demonstrates the information of every single study according to the year of studies conducted, the first author, and the final outcome of the studies. The random effects analysis has been used to estimate the overall prevalence as it is mentioned at the bottom of the figure. This figure displays the estimation of each study with square and the $95 \%$ confidence interval for the relevant estimation with a horizontal line. Square size shows the weight of each study in meta-analysis. The diamond shown at the bottom of the figure indicates the weight of all squares. Horizontal diameter of the diamond shows the possible range of prevalence outcome. Two vertical lines are shown in the figure. The dotted vertical line which is in line with diamond vertical axis shows the overall meta-analysis outcome (pooled prevalence). Another continuous vertical line shows the null hypothesis or no effect which is zero in prevalence, incidence, and means 
Table 2 Prevalence of needlestick injuries in each subgroup

\begin{tabular}{|c|c|c|c|c|c|c|c|c|}
\hline \multirow[t]{2}{*}{ Variables } & \multirow[t]{2}{*}{ Groups } & \multirow{2}{*}{$\begin{array}{l}\text { Number } \\
\text { of } \\
\text { studies }\end{array}$} & \multirow{2}{*}{$\begin{array}{l}\text { Sample } \\
\text { size }\end{array}$} & \multirow[t]{2}{*}{ Prevalence } & \multirow{2}{*}{$\begin{array}{l}95 \% \\
\text { confidence } \\
\text { interval }\end{array}$} & \multicolumn{3}{|c|}{ Heterogeneity } \\
\hline & & & & & & $\bar{P}$ & Q & $1^{2}$ \\
\hline \multirow[t]{2}{*}{ Gender } & Male & 11 & 1571 & 42 & $26-58$ & 98.4 & 619.07 & 0.0001 \\
\hline & Female & 11 & 2609 & 47 & $36-58$ & 97.4 & 380.2 & 0.0001 \\
\hline \multirow[t]{2}{*}{ Tool } & Researcher-made & 39 & 12,780 & 43 & $36-50$ & 98.6 & 2769.03 & 0.0001 \\
\hline & Other & 5 & 3325 & 36 & $29-43$ & 93.7 & 63.55 & 0.0001 \\
\hline \multirow[t]{4}{*}{ Sampling method } & Random & 9 & 3231 & 42 & $29-55$ & 98.4 & 506.97 & 0.0001 \\
\hline & Census & 15 & 5835 & 43 & $34-52$ & 98.3 & 840 & 0.0001 \\
\hline & Other & 6 & 795 & 50 & $38-62$ & 92.1 & 63.09 & 0.0001 \\
\hline & Unknown & 14 & 6244 & 39 & $29-48$ & 98.8 & 1090.25 & 0.0001 \\
\hline \multirow[t]{2}{*}{ Type of hospital } & Teaching & 41 & 14,392 & 43 & $37-49$ & 98.6 & 2917.03 & 0.0001 \\
\hline & Military & 3 & 1713 & 34 & $30-38$ & 20 & 2.50 & 0.286 \\
\hline
\end{tabular}

conditions and standards, overcrowding of patients, hospital ward, type of health care personnel, and their skills. Context, culture, and access to resources are the main reasons for the difference in the prevalence of NSIs in these societies. Types of hospital policies, rules and regulation, and the way infection control nurses taking hard on the staff make many of the employees never report their injuries. On the other hand, many personnel get confused and do not know where to report and what forms to complete after NSIs due to rapid changes in the hospitals' guidelines and policies [66]. Dissatisfaction with follow-up by administrators after reporting the events, low risk perception, and time-consuming protocol $[66,67]$ are some other reasons for underreporting NSIs. Therefore, employees prefer not to report their injuries. Thus, this will cause the validity of existing data to be disrupted to some extent.

In general, half of the HCWs experience NSIs during their working career [68]. However, NSIs have not been reported by victims in many cases due to various reasons previously listed. Thus, the actual rate of NSIs may be underestimated. In the present study, the prevalence of

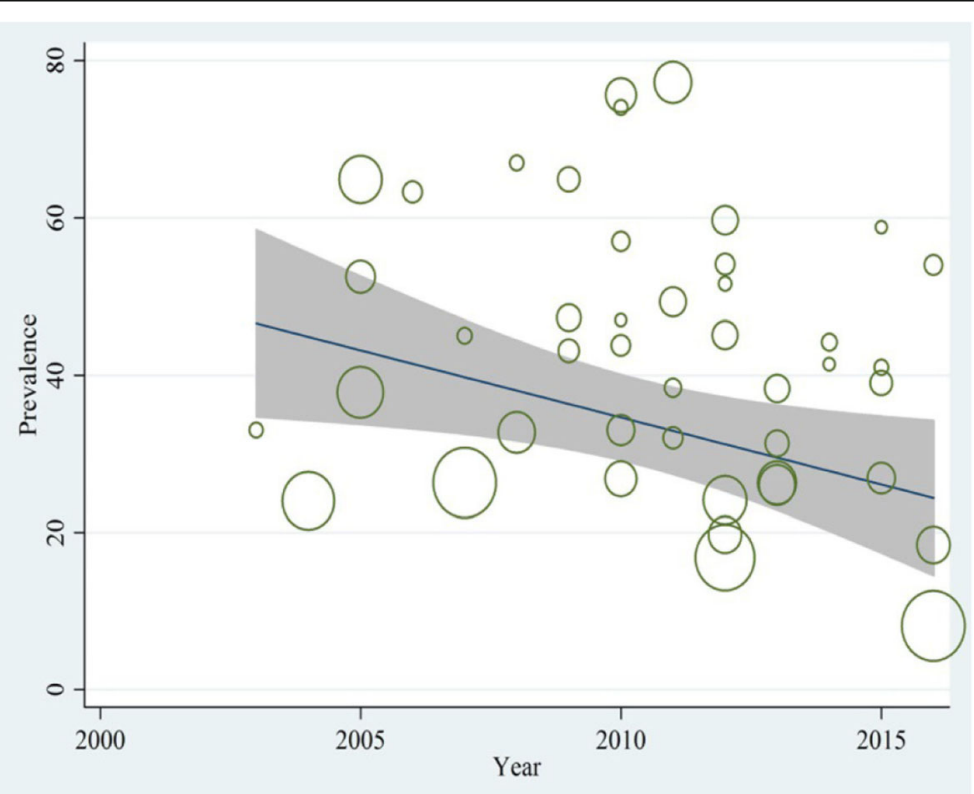

Fig. 3 Reduction in prevalence of NSIs during 2003-2016 according to meta-regression. This figure shows meta-regression analysis of needlestick prevalence based on selected studies' publication years. The vertical axis represents the prevalence, and the horizontal axis represents the selected studies' publication year. Slope of the regression line indicates an increase or decrease of study effect using REML estimation. Given the slope of the regression line is descending in this figure, it can be inferred that as the studies' publication year has been increased, the prevalence of needlestick has been decreased. Gray color lines around the slope of the regression line indicate $95 \%$ confidence interval. Each circle demonstrates one selected study and the size of each circle corresponds to the weight assigned to each study. Reverse weight corresponds to the standard error of each study 


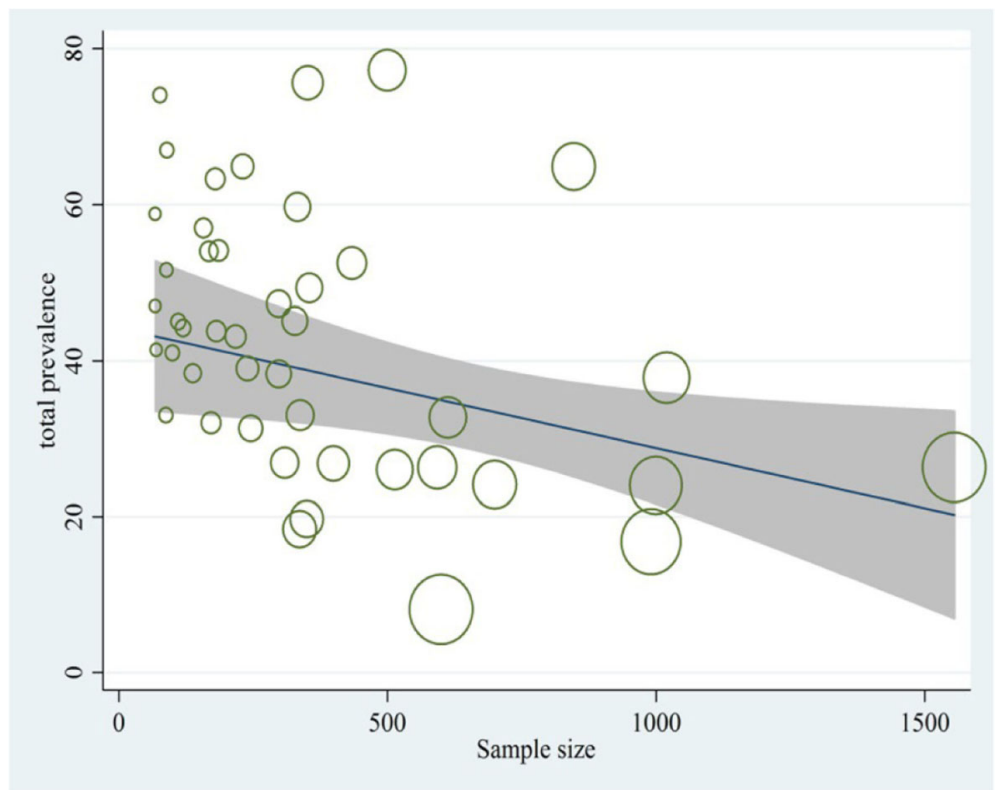

Fig. 4 Total prevalence of NSIs based on the sample size of selected studies by meta-regression analysis. Circles show the weight of the studies. The figure indicates a significant association between the prevalence of NSIs and sample size. The prevalence rate was reduced significantly with a rise in sample size

NSIs was reported to be $42 \%$, which was reduced by $16 \%$ compared to the results of the study by Sayehmiri et al. on the prevalence of NSIs in Iran [69]. This reduction in the prevalence rate could be due to underreporting of NSIs, which may be associated with the time-consuming nature of reporting the injuries, believing in the low risk of NSIs for transmission disease, being unwilling or lacking the time for follow-ups and treatment [70]. Because of the high prevalence of NSIs, there have been efforts to provide more safety training, awareness, and workshops. And because of better knowledge among HCWs, there is reduction in

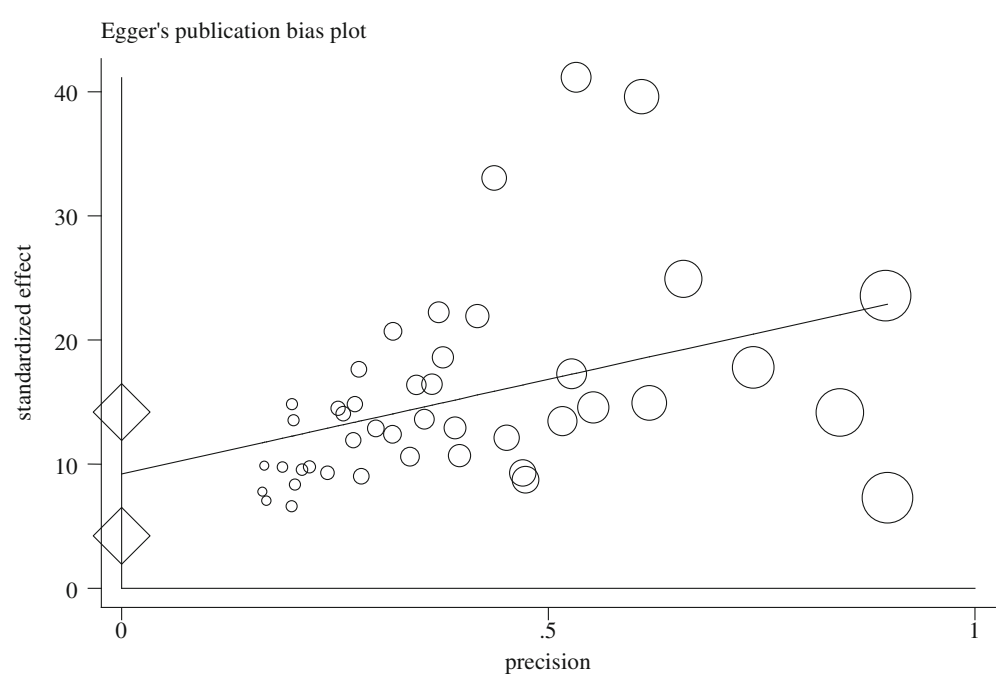

Fig. 5 Publication bias. This figure is used to investigate the publication bias of studies. Circles show selected studies, and the area of each circle is equivalent to the weight of each study. The horizontal axis represents accuracy, and the vertical axis represents the standardized effect. The line shown in this figure is a regression line related to Egger's regression test. It shows that whether this line cut the vertical axis at the point near zero or not. If this line distance from zero, it indicates a bias in publishing the results. If there is no publication bias, it is expected that this line passes from origin to a point near the origin. Since intercept (width from origin) is close to 9 in this figure, we conclude that publication bias is significant. Two diamonds that are plotted on the vertical axis indicate confidence interval corresponds to the coefficient obtained from the regression test $\beta_{-} 1$ that it is 4.2 to 14.1. Because zero is not included in the confidence interval. Therefore, it could be concluded that the publication bias is significant 
prevalence. This could be one of the reasons for reducing of the prevalence in our study. Several studies reported the necessity of holding educational class in order to prevent NSIs and reduce the prevalence of NSIs $[26,69]$.

Further, the findings indicated that the prevalence of NSIs was more in women compare to men. Since the number of female healthcare workers is several times higher than males in Iranian hospitals [26], female nurses have more responsibilities than male nurses [63] and women are more likely to be stressed than men [71]. A study showed that HCWs who had job-related stress were 7.3 times more likely to face NSIs [72]. This finding is in line with the results of studies conducted in Ethiopia and Saudi Arabia [73, 74]. The study of Shah et al. showed women suffered from NSIs twice more than men [63]. Kebede et al. reported that half of NSIs occurred in women [75]. Similar to our result, recent studies showed that women are more likely to report injuries, follow the tests and post-traumatic care compared to men because of feeling pain or worrying about bloodborn infectious diseases following NSIs $[2,55]$.

Moreover, the prevalence of NSIs was more in nurses than in other HCWs, confirming the results of studies carried out in India and Georgia [76, 77]. Similar to our findings, the systematic review of Khraisa et al. showed the prevalence of NSIs was higher in nurses than other HCWs in hospitals (64\% vs. 44\%) [78]. A study conducted in Jordan reported the maximum and minimum prevalence rates of NSIs in nurses $(81 \%)$ and midwives (1\%) [64]. The findings of a study in Pakistan showed the female nurses have a higher prevalence rate of NSIs than other professionals [79]. In the research carried out by Yoshikawa et al., NSIs occurred in nurses three times more than other HCWs [80]. In line with our findings, a study conducted in Portugal by Martins et al. reported the most NSIs occurred in female nurses compared to other HCWs [81]. Similar to other study results, our findings indicate high prevalence of NSIs in nurses is due to high workload, increased sharp objects exposure, inadequate staffing, and long working hours $[11,13,75]$. In addition, our findings indicate that the prevalence of NSIs was higher at teaching hospitals than military hospitals. This may be due to overcrowding and understaffed shifts, or better reporting of NSIs, or special policies of hospital management in these regions and these types of hospitals.

Reviewing literature shows that the incident of NSIs is associated with three main factors: engineering (the form of devices), organizational (injury reporting policies), and behavioral (recapping needles and disposing of them) factors [13]. A review of the literature showed that those three factors have not mentioned clearly in studies conducted in Iran. However, according to the results, the cause of most injuries was reported to be behavioral factors such as recapping the needle $[10,69]$. Our results indicated behavioral factors play important role in our health care settings. In spite of frequent education, many of the staff still are insistent on recapping needles. Unfortunately, this behavior remains the main cause of many NSIs. Various studies have reported that recapping has been the most common cause of NSIs in Iranian hospitals $[10,69]$.Thus, teaching safe injection methods [23] as well as correct use and disposal of sharp objects (standard precautions), safety-engineered device (SED) $[13,16,23]$, which involves replacing conventional needles with safe needles, and teaching the correct use of safe needles have been proposed as the most important strategies to decrease the incidence and prevalence of NSIs. Adams believes that use of safe-engineered devices is more effective to reduce NSIs than developing policies, regular training of personnel and the use of personal protective equipment [82]. According to our clinical experience, new hospital guidelines and policies are presented more often to the staff in this regard, while the safe-engineered devices and personal protective equipment are not sufficiently available to personnel.

Some limitations of the current study included inadequate information of some articles, irregular distribution of studies around the country, small sample size, and unknown sampling method of some studies. Reporting an accurate estimate of this problem in Iran and comparing with other countries via meta-analysis highly recommended. We also suggest further studies to be conducted to investigate and compare the prevalence of NSIs in dentists, nursing and medical students, and housekeeping staff with other HCWs.

\section{Conclusions}

The results of the present study indicated a relatively high frequency of NSIs. Non-compliance with specific standards on using of equipment, wearing protective devices, and disposing of sharp objects can play a pivotal role in increasing the possible risk of NSIs in the HCWs. Needlestick and sharps injuries can be reduced by taking such measures as supplying standard and safe equipment, holding training workshops regarding safety issues at work environment, providing enough staffing, and cutting down working hours.

\section{Implication for practice}

Considering the high prevalence of NSIs among the Iranian HCWs, hospital managers are advised to introduce and adopt restructured guidelines and to supply safe needles and instruments for employees. They also need to develop and implement preventive programs such as installing safety enhanced devices $[14,21]$ in health sectors like needle cutter machines and adequate safety disposal boxes 
[2, 23]. Infection control managers/nurses need to hold training programs [23] focused on new methods of using sharp objects safely, observe safety principles and standards, and reinforce the practical skills of personnel. Because more than half of HCWs in Iran do not report their NSIs and expose themselves to the harmful consequences. Thus, nursing managers must try to break this culture of silence [8] with proper actions such as following up the incident seriously, facilitating the reporting process [2], and taking easy on the employees who receive these injuries. They also need to pay more attention to reporting and improving occupational behaviors such as avoiding recapping the needles [54] in order to decrease the incidence of NSIs and consequently reduce blood-transmitted infectious diseases. Nurse education specialists can provide educational activities to personnel to improve the knowledge and skills necessary to deal with this problem by different methods such as seminars, informative educational boards, pamphlets, and workshops [5, 22, 79]. Also, nursing researchers and policy-makers may develop standard tools like national surveillance for reporting NSIs in the entire country to help injured personnel's and victims' private information remains confidential in order to avoid social stigma.

\section{Abbreviations}

BBPs: Bloodborne pathogens; HCWs: Health care workers; NSIs: Needlestick and sharps injuries

\section{Acknowledgements}

The authors wish to appreciate all the researchers whose articles were used in the present research. We would also like to thank Mariam Angelica Parizad for her review of the manuscript.

\section{Funding}

This research did not receive any specific grant from funding agencies in the public, commercial, or not-for-profit sectors.

\section{Availability of data and materials}

All data generated or analyzed during this study are included in this published article [and its supplementary information files].

\section{Authors' contributions}

NP, RGG, MA, and SD designed the study. NP, FS, RGG, and SD helped in the data collection. SD, RGG, MA, and FS contributed to the analysis and interpretation of data. NP, RGG, FS, and MA carried out the manuscript preparation. FS, NP, RGG, and SD helped in the manuscript revision. All authors read and approved the final manuscript before submission.

Ethics approval and consent to participate

Not applicable.

\section{Consent for publication}

Not applicable.

\section{Competing interests}

The authors declare that they have no competing interests.

\section{Publisher's Note}

Springer Nature remains neutral with regard to jurisdictional claims in published maps and institutional affiliations.

\section{Author details}

Clinical Care Research Center, Kurdistan University of Medical Sciences, Sanandaj, Iran. ${ }^{2}$ Shahid Beheshti Hospital of Hamadan, Hamadan University of Medical Sciences, Hamadan, Iran. ${ }^{3}$ Department of Nursing, University of Social Welfare and Rehabilitation Sciences, Tehran, Iran. ${ }^{4} \mathrm{MSc}$ of Biostatistics, Health Promotion Research Center, Iran University of Medical Sciences,

Tehran, Iran. ${ }^{5}$ Department of Medical-Surgical Nursing, School of Nursing and Midwifery, Urmia University of Medical Sciences, Pardis Nazlou, $11 \mathrm{~km}$ of Nazlou Road, Urmia, Iran.

Received: 19 April 2018 Accepted: 22 August 2018

Published online: 07 September 2018

\section{References}

1. Ongete G, Duffy FJR. The impact of occupational splash, sharps and needlestick injuries (SSNIs) on the quality of life of healthcare workers in a Kenyan university hospital. Work. 2018:59:103-19. https://doi.org/10.3233/ WOR-172664.

2. Ghanei Gheshlagh R, Zahednezhad H, Shabani F, Hameh M, Ghahramani M, Farajzadeh $\mathrm{M}$, et al. Needle sticks injuries and its related factors among nurses. Iran J Nurs. 2014;27:21-9. Available at: http://ijn.iums.ac.ir/article-11833-en.html

3. Wicker S, Jung J, Allwinn R, Gottschalk R, Rabenau HF. Prevalence and prevention of needlestick injuries among health care workers in a German university hospital. Int Arch Occup Environ Health. 2008;81:347-54. https:// doi.org/10.1007/s00420-007-0219-7.

4. Desalegn Z, Gebreselassie S, Asemamaw Y. Epidemiology of needle sticksharp injuries (NSSIs) and potential high risk exposures among health professionals in Ethiopia: neglected public health concern. Am J Health Res. 2015;3:298-304. https://doi.org/10.1016/j.jij.2016.02.558.

5. Adib-Hajbaghery M, Lotfi MS. Behavior of healthcare workers after injuries from sharp instruments. Trauma mon. 2013;18:75-80. https://doi.org/10. 5812/traumamon.12779.

6. Baghcheghi $\mathrm{N}$, Koohestani $\mathrm{H}$, Abedi A. Prevalence needlestick/sharps injuries among nursing student and related factor. Iran Occup Health. 2011;7:31-9. Available at: http://ioh.iums.ac.ir/article-1-393-en.html

7. World health organization. The world health report 2002: reducing risks, promoting healthy life: World Health Organization; 2002. Available at: http:// www.who.int/whr/2002/en/

8. Ghanei Gheshlagh R, Fallahi KM. Needle stick injuries, culture of silence: a systematic review. J Health Promot Manag. 2015:4:31-50. Available at: http://jhpm.ir/article-1-407-en.html

9. Sharma R, Rasania S, Verma A, Singh S. Study of prevalence and response to needle stick injuries among health care workers in a tertiary care hospital in Delhi, India. Indian J Community Med. 2010;35:74-7. https://doi.org/10.4103/ 0970-0218.62565.

10. Geravandi S, Alavi SM, Yari AR, Yousefi F, Hosseini SA, Kamaei S, et al. Epidemiological aspects of needle stick injuries among health care workers in Razi Hospital Ahvaz, Iran, in 2015. Arch Hyg Sci. 2016;5:85-91. Available at: http://jhygiene.muq.ac.ir/article-1-88-en.html

11. Bhardwaj A, Sivapathasundaram N, Yusof M, Minghat A, Swe K, Sinha N. The prevalence of accidental needle stick injury and their reporting among healthcare workers in orthopaedic wards in general hospital Melaka, Malaysia. Malaysian Orthop Journal. 2014;8:6-13. https://doi.org/10.5704/ MOJ.1407.009

12. Khraisat FS, Juni MH, Salmiah M, Rahman AA, Hamdan-Mansour A. Needle stick injuries prevalence among nurses in Jordanian hospitals. Internationa journal of public health and clinical. Sci. 2015;2:7-16. Available at: http:// www.publichealthmy.org/ejournal/ojs2/index.php/ijphcs/article/view/196

13. Cho E, Lee H, Choi M, Park SH, Yoo IY, Aiken LH. Factors associated with needlestick and sharp injuries among hospital nurses: a cross-sectional questionnaire survey. Int J Nurs Stud. 2013;50:1025-32. https://doi.org/10. 1016/j.jijnurstu.2012.07.009

14. Irmak Z. Needlestick and sharps injury among nurses at a state hospital in Turkey. Aust J Adv Nurs. 2012;30:48-55. Available at: https://search.informit. com.au/documentSummary;dn=089813477479400;res=IELAPA

15. Ghanei Gheshlagh R, Nazari M, Baghi V, Dalvand S, Dalvandi A, Sayehmiri K. Underreporting of needlestick injuries among healthcare providers in Iran: a systematic review and meta-analysis. J Hayat. 2017;23:201-13. Available at: http://hayat.tums.ac.ir/article-1-1941-en.html 
16. Elder A, Paterson C. Sharps injuries in UK health care: a review of injury rates, viral transmission and potential efficacy of safety devices. Occup Med. 2006;56:566-74. https://doi.org/10.1093/occmed/kql122.

17. Haghdoost AA, Moosazadeh M. The prevalence of cigarette smoking among students of Iranâ€ ${ }^{\mathrm{TM}} \mathrm{S}$ universities: a systematic review and metaanalysis. J Res Med Sci. 2013;18:717-25. Available at: http://jrms.mui.ac.ir/ index.php/jrms/article/view/9454

18. Moosazadeh M, Nekoei-moghadam M, Emrani Z, Amiresmaili M. Prevalence of unwanted pregnancy in Iran: a systematic review and meta-analysis. Int J Health Plann Manag. 2014;29:e277-e90.

19. Meline T. Selecting studies for systematic review: inclusion and exclusion criteria. Contemp Issues Commun Sci Disord. 2006;33:21-7. Available at: https://pdfs.semanticscholar.org/a6b4/ d6d01bd19a67e794db4b70207a45d47d82f3.pdf

20. Moher D, Liberati A, Tetzlaff J, Altman DG, Group P. Preferred reporting items for systematic reviews and meta-analyses: the PRISMA statement. PLoS Med. 2009:6:e1000097. https://doi.org/10.1136/bmj.b2535.

21. Balouchi A, Shahdadi H, Ahmadidarrehsima S, Rafiemanesh $H$. The frequency, causes and prevention of Needlestick injuries in nurses of Kerman: a cross-sectional study. J Clin Diagn Res. 2015;9:13-5. https://doi. org/10.7860/JCDR/2015/16729.6965.

22. Hajivandi A, Ramavandi B, Rezaeeshiri A, Ahmadi B. A survey on the sharpand cutting wastes injury in nurses of the Bushehr city hospitals in the year 1392. J Urmia Nurs Midwifery Fac. 2015;13:490-7. Available at: http:// eprints.umsu.ac.ir/id/eprint/4005

23. Jahangiri M, Rostamabadi A, Hoboubi N, Tadayon N, Soleimani A. Needle stick injuries and their related safety measures among nurses in a university hospital, Shiraz, Iran. Saf Health Work. 2016;7:72-7. https://doi.org/10.1016/j. shaw.2015.07.006.

24. Mirzaei-Alavijeh M, Jalilian F, Karami-Matin B, Ghaderi A, Mahboubi M, Janizadeh $R$, et al. Needle-stick and medication errors in emergency nurses are due to their job stresses? A descriptive study in Kermanshah Hospitals, Iran. J Biol Today's World. 2014;3:185-8. Available at: http://sdh.yums.ac.ir/ uploads/Needle_-_Stick_and_Medication.pdf

25. Salmanzadeh S, Rahimi Z, Goshtasbipour M, Meripoor M. The prevalence of needle-stick injuries among healthcare workers in Dasht-e-Azadegan, southern west of Iran. International Journal of Pharmaceutical Research \& Allied. Sci. 2016;5:417-22. Available at: https://pdfs.semanticscholar.org/f8d1/ 63fa0ce54d737548c61309b7131a3d74fe56.pdf?_ga=2.265225103. 1640492555.1519337271-1425086663.1519337271

26. Izadi N, Chavoshi F, Sadeghi M. Needlesticks and Sharps injuries among the personnel of Baharlou Hospital in Tehran, Iran. Jundishapur J Health Sci. 2015;7:e30649. https://doi.org/10.17795/jjhs-30649.

27. Shoghli A, Mousavi Nasab N, Ghorchian F, Masoumi H, Momtazi S. Study of the needle sticks injury (NSI) among the Zanjan Educational Hospitals staff. J Zanjan University Med Sci Health Serv. 2013;21:131-41. Available at: http:// zums.ac.ir/journal/article-1-2148-en.html

28. Shadi R, Rabi Rad N, Tamizi Z, Fallahi Khoshkenab M, Mohamad Nezhad E. An investigation in to occupational hazard faced by nurses in pediatrics hospitals of Tehran University of Medical Sciences, 2006-2009. Int J Commun Based Nursing Midwifery. 2013;1:200-7. Available at: http://ijcbnm. sums.ac.ir/index.php/ijcbnm/article/view/61

29. Bijani B, Azimian J, Soleimany MA, Mohammadi N. Epidemiology and risk factors of needle stick injuries among nurses in Bou-Ali Sina teaching hospital, Qazvin. Adv Nurs Midwifery 2013;22:1-9.

30. Tirgar A, Gholami F. A survey on needlestick injuries and related occupational factors among the nurses. Mod Rehabil. 2012;1:31-8. Available at: http://jhsw.tums.ac.ir/article-1-21-en.html

31. Sharifian S, Aminian O, Afsharisaleh L. Occupational stress and its relationship with need lestick injury among emergency department personnel. Occup Med Q J (TKJ). 2012;3:7-13. Available at: http://tkj.ssu.ac.ir/ article-1-84-en.html

32. Rezaei SRN, Tamizi ZS, Fallahi Khoshknab M, Mohammad Nejad E, Mahmoodi M. Needle sticks injuries among health care workers in emergency medical centers in Tehran University of Medical Sciences hospitals (2007-2010). J Health Promot Manag. 2012;1:46-55. Available at: http://jhpm.ir/article-1-81-en.html

33. Nejadghaderi $M$, Safizadeh $H$, Khanjani $N$. The knowledge and practice of medical staff about needle injuries in Rafsanjan's Ali-ebne-Abitaleb hospital, Iran. J Health Dev. 2012;1:1-10. Available at: http://jhad.kmu.ac.ir/article-1121-en.html.
34. Hashemi S, Torabian S, Mamani M, MOAZEN DS. The prevalence of needlestick and sharps injuries among health care workers in Hamadan, Iran. Sci J Hamadan Univ Med Sci Health Ser. 2012;18:41-6. Available at: http://sjh.umsha.ac.ir/article-1-212-en.html.

35. Ghannad MS, Majzoobi MM, Ghavimi M, Mirzaei M. Needlestick and sharp object injuries among health care workers in Hamadan Province, Iran. J Emerg Nurs. 2012;38:171-5. https://doi.org/10.1016/j.jen.2011.01.009.

36. Bijani B, Sotudehmanesh S, Mohammadi N. Epidemiological features of needle stick injuries among nursing staff. J Guilan Univ Med Sci. 2011;77:618. Available at: http://journal.gums.ac.ir/article-1-160-en.html

37. Ehsani SR, Mohammadnejad E, Hadizadeh MR, Mozaffari J, Ranjbaran S, Deljo R, et al. Epidemiology of needle sticks and sharp injuries among nurses in an Iranian teaching hospital. Arch Clinic Infect Dis. 2012:8:27-30. https://doi.org/10.5812/archcid.14409.

38. Mohammadi N, Allami A, Malek Mohamadi R. Percutaneous exposure incidents in nurses: knowledge, practice and exposure to hepatitis B infection. Hepat Mon. 2011;11:186-90. Available at: https:/www.ncbi.nlm.nih.gov/pubmed/22087141

39. Rahnavard F, Reza Masouleh S, Seyed Fazelpour F, Kazemnejad Leili E. Study factors related to report the needle stick and sharps injuries report by nursing staffs of the educational and therapeutic centers of Guilan University of Medical Sciences, Rasht. Holis Nurs Midwifery J. 2011;21:30-7. Available at: http://hnmj.gums.ac.ir/article-1-191-en.html

40. Shiva F, Sanaei A, Shamshiri AR, Ghotbi F. Survey of needle-stick injuries in paediatric health personnel of 5 university hospitals in Tehran. J Pak Med Assoc. 2011;61:127-31. Available at: https:/www.ncbi.nlm.nih.gov/pubmed/21375158

41. Nasiri $E$, Vahedi $M$, Siamian $H$, Mortazavi $Y$, Jafari $H$. Needle sticks injury with contaminated blood in the special unit. S Staff Middle-East J Sci Res. 2010;5: 61-4. Available at: https://www.idosi.org/mejsr/mejsr5(2)/2.pdf

42. Gholami A, Salarilak S, Alinia T, Nejad Rahim R. Study of needle stick injuries among health Care Workers at Teaching Hospitals in Urmia. Iranian J Epidemiol. 2010;6:57-61. Available at: http://irje.tums.ac.ir/article-1-78-en.html

43. Heidari M, Shahbazi S. Prevalence of needle sticks exposure in operation room's staff of Borujen \& Lordegan hospitals-2010-2011. CommunHealth J. 2010:5:32-7. Available at: http://eprints.skums.ac.ir/id/eprint/6371

44. Khalouei A, Iranpour A, Hamzehnezhadi S, Rahmanian KE. Study on epidemiology of needle stick injury among nursing personnel of Kerman university hospital, Kerman, Iran in (2006-2007) journal of Jahrom University of Medical. Sci. 2010;7:42-9. Available at: http://www.sid.ir/En/Journal/ ViewPaper.aspx?ID=169367.

45. Mohammadi Nejad E, Esfand Bod M, Ehsani SR, Deljoo R. Needlestick injuries and reporting among emergency nurses in Tehran University of Medical Science. Iranian Journal of Infectious Disease and Tropical. Medicine. 2010;48: 49-54. Available at: http://www.sid.ir/En/Journal/NiewPaper.aspx?ID=274945

46. Moradi A, Mostafavi E, Moradi A. The prevalence and causes of needle stick injuries among the primary health care workers of Bahar city, Hamadan Province. Iran Occup Health. 2010;7:39-42. Available at: http://ioh.iums.ac.ir/ article-1-289-en.html

47. NS AM, Hamidizade S, Jamali F, Pournoroz N. Survey of accidental injuries caused by sharp instruments among the Jahrom university of medical sciences hospitals health care workers, 2008. J Jahrom University Med Sci(JJUMS). 2009;7:30-8.

48. Kazemi Galougahi MH. Evaluation of needle stick injuries among nurses of Khanevadeh Hospital in Tehran. Iran J Nurs Midwifery Res. 2010;15:172. Available at: https://www.ncbi.nlm.nih.gov/pmc/articles/PMC3093184/

49. Ghasemi A, Eatemad E, Pour Mohammad Jan N, Bashiri J, Habibzadeh Sh. Pour Mohammad Jan N, Bashiri J, Habibzadeh Sh. . Effect of needle stick injuries associated factors on two group of nurses and service workers in hospitals of Ardabil. Journal of Infectious Diseases and Tropical. Med. 2009; 14:27-32. Available at: http://www.iiccom.org/JOURNAL/PDF/46/6.PDF.

50. Mohammad Nejad E, Esfandbod M. Epidemiologic aspects of the nurse's occupational exposure to sharp objects. Iranian Journal of Infectious Diseases and Tropical. Med. 2009;45:47-50. Available at: http://www.iiccom. org/JOURNAL/PDF/45/9.PDF.

51. Jonaidi Jafari N, Shasti M, Izadi M, Ranjbar R, Ghasemi M. Evaluation of frequency of exposure to medical sharp devices among nurses of a university hospital. J Military Med. 2008;10:119-28. Available at: http://militarymedj.ir/article-1-576-en.html

52. Lotfi R, Gashtasbi A. Needle stick and sharps injuries and its risk factors among health center personnel (Astara; Iran, 2006). Journal of Babol University of Medical. Sci. 2008;10:71-7. Available at: http://www.sid.ir/En/ Journal/ViewPaper.aspx?ID=129055

53. Azadi M, Anoosheh M. Needle stick injuries among clinical nurses. Iran J Nurs 2007;20:6-14. Available at: http://ijn.iums.ac.ir/article-1-264-en.html 
54. Askarian M, Shaghaghian S, McLaws M-L. Needlestick injuries among nurses of Fars province. Iran Ann Epidemiol. 2007;17:988-92. https://doi.org/10. 1016/j.annepidem2007.07.106.

55. Ebrahimi H, Khosravi A. Needlestick injuries among nurses. J Res Health Sci. 2007;7:56-62. Available at: https://www.ncbi.n/m.nih.gov/pubmed/23343925

56. Nejadrahim $R$, Gharahughi N, Sistanizade M. Needlestick injuries in the health care workers of Urmia educational hospitals. J Urmia Nurs Midwifery Fac. 2005;3:1-10. Available at: http://unmf.umsu.ac.ir/browse.php?a_id=172\&sid=1\&slc_lang=en

57. Vahedi M, Ahsan B, Ardalan M, Prevalence SS. Causes of needle stick injuries, in medical personals of Kurdistan University's hospitals and dealing with such injuries due to contaminated sharp tools in 1383. Scientific Journal of Kurdistan University of. Med Sci. 2006;1 1:43-50. Available at: https:/sjku.muk.ac.ir/article-1-144-en.html

58. Hoseini Shokouh SJ, Ahmadi M. Knowledge and practice of health care workers about needle stick injury and blood borne pathogens in army 505 hospitals. J Ardabil Univ Med Sci 2003;1:119-124. Available at: http://www. sid.ir/En/Journal/ViewPaper.aspx?ID=58343.

59. Nazmieh H, Najaf-Yarandi A, Janmohammadi S, Hosseini F. Assessment of the injuries caused by sharp instruments in the health workers of university hospitals, in Yazd. Iran J Nurs. 2005;18:49-59. Available at: http://ijn.iums.ac. ir/article-1-9-en.html.

60. Poorolajal J, Hadadi A, Asasi N, Mohammad K. Frequency of occupational exposure to blood or other potentially infectious materials and related factors in healthcare workers in Hamadan-2003. Iran J Infect Dis. 2004;27:19. Available at: http://www.sid.ir/Fa/Journal/NiewPaper.aspx?id=16827.

61. Mahmoudi N, Sepandi M, Mohammadi AS, Masoumbeigi H. Epidemiological aspects of needle stick injuries among nurses in a military hospital. Iran J Health, Safety Environ. 2015;2:374-9. Available at: www.ijhse.ir/index.php/ IJHSE/article/download/102/pdf_49

62. Rakhshani F, Heidari M, Barati S. Prevalence of needle stick injuries among the healthcare professionals in Zahedan Medical Sciences University. Iran J Epidemiol. 2009;4:87-91. Available at: http://irje.tums.ac.ir/article-1-137-en.html

63. Shah SF, Bener A, Al-Kaabi S, Al Khal AL, Samson S. The epidemiology of needle stick injuries among health care workers in a newly developed country. Saf Sci. 2006:44:387-94. https://doi.org/10.1016/.jssci.2005.11.002.

64. Hassan ZM, Wahsheh MA. Occupational exposure to sharp injuries among Jordanian health care workers. Infect Dis Clin Pract. 2009;17:169-74. https:// doi.org/10.1097/IPC.0b013e31819b8d10.

65. Siddique K, Mirza S, Tauqir SF, Anwar I, Malik AZ. Knowledge attitude and practices regarding needle stick injuries amongst healthcare providers. Pakistan J Surg. 2008;24:243-8. Available at: www.pjs.com.pk/journal_pdfs/ oct_dec08/08_NeedleSticklnjury.pdf

66. Voide C, Darling KE, Kenfak-Foguena A, Erard V, Cavassini M, Lazor-Blanchet C. Underreporting of needlestick and sharps injuries among healthcare workers in a Swiss University Hospital. Swiss Med Wkly. 2012;142:1-7. https://doi.org/10.4414/smw.2012.13523.

67. Azadi A, Anoosheh M, Delpisheh A. Frequency and barriers of underreported needlestick injuries amongst Iranian nurses, a questionnaire survey. J Clin Nurs. 2011;20:488-93. https://doi.org/10.1111/j.1365-2702.2010.03252.x.

68. Bairami F, Kasani E, Ghorbanpoor M, Bairami A, Pasban-Noghabi S. Needlestick and sharp injuries incidents among healthcare workers: an updated survey in Iran. Int J Hosp Res. 2014;3:79-82. Available at: http://ijhr.iums.ac.ir/ index.php/article_6122.html

69. Sayehmiri K, Mohammadi E, Mohammadi I, Sayehmiri F. Epidemiology of needle sticks and sharps injuries in healthcare workers in Iran: a systematic review and meta-analysis. Iran Occupational Health. 2014;11:93-103. Available at: http://ioh.iums.ac.ir/article-1-1130-en.html

70. Kennedy R, Kelly S, Gonsalves S, Mc Cann P. Barriers to the reporting and management of needlestick injuries among surgeons. Ir J Med Sci. 2009;178: 297-9. https://doi.org/10.1007/s11845-009-0359-8.

71. Yada $\mathrm{H}$, Abe H, Omori $\mathrm{H}$, Matsuo $H$, Masaki O, Ishida $Y$, et al. Differences in job stress experienced by female and male J apanese psychiatric nurses. Int J Ment Health Nurs. 2014;23:468-76. https://doi.org/10.1111/inm.12080.

72. Dilie A, Amare D, Gualu T. Occupational exposure to needle stick and sharp injuries and associated factors among health care workers in Awi Zone, Amhara Regional State, Northwest Ethiopia, 2016. J Environ Public Health. 2017; https://doi.org/10.1155/2017/2438713.

73. Reda AA, Fisseha S, Mengistie B, Vandeweerd J-M. Standard precautions: occupational exposure and behavior of health care workers in Ethiopia. PLoS One. 2010;5:e14420. https://doi.org/10.1371/journal.pone.0014420.
74. Jahan S, Buraidah A. Epidemiology of needlestick injuries among health care workers in a secondary care hospital in Saudi Arabia. Ann Saudi Med. 2005;25: 233-8. Available at: https:/www.ncbi.nlm.nih.gov/pubmed/16119525

75. Kebede G, Molla M, Sharma HR. Needle stick and sharps injuries among health care workers in Gondar city, Ethiopia. Saf Sci. 2012;50:1093-7. https:// doi.org/10.1016/j.ssci.2011.11.017.

76. Jaybhaye D, Dahire P, Nagaonkar A, Vedpathak V, Deo D, Kawalkar U. Needle stick injuries among health care workers in tertiary care hospital in tertiary care hospital of rural India. Int J Med Sci Public Health. 2014;3:49-52. https://doi.org/10.5455/ijmsph.2013.230920133.

77. Butsashvili M, Kamkamidze G, Kajaia M, Morse D, Triner W, Dehovitz J, et al Occupational exposure to body fluids among health care workers in Georgia. Occup Med. 2012;62:620-6. https://doi.org/10.1093/occmed/kqs121.

78. Khraisat FS, Juni MH, Rahman AA, Said SM. Needlestick and sharp injuries among healthcare workers in hospitals: a mini-systematic review. Int J Clinic Med Res. 2014;1:151-60. Available at: http://psasir.upm.edu.my/id/eprint/34633/

79. Afridi AAK, Kumar A, Sayani R. Needle stick injuries-risk and preventive factors: a study among health care workers in tertiary care hospitals in Pakistan. Glob J Health Sci. 2013;5:85-92. https://doi.org/10.5539/gjhs.v5n4p85.

80. Yoshikawa T, Wada K, Lee JJ, Mitsuda T, Kidouchi K, Kurosu H, et al. Incidence rate of needlestick and sharps injuries in 67 Japanese hospitals: a national surveillance study. PLoS One. 2013:8:e77524. https://doi.org/10. 1371/journal.pone.0077524.

81. Martins A, Coelho AC, Vieira M, Matos M, Pinto ML. Age and years in practice as factors associated with needlestick and sharps injuries among health care workers in a Portuguese hospital. Accid Anal Prev. 2012;47:11-5. https://doi.org/10.1016/j.aap.2012.01.011.

82. Adams D. Needlestick and sharps injuries: practice update. Nurs Stand. 2012; 26:49-57. https://doi.org/10.7748/ns2012.05.26.37.49.c9107.
Ready to submit your research? Choose BMC and benefit from:

- fast, convenient online submission

- thorough peer review by experienced researchers in your field

- rapid publication on acceptance

- support for research data, including large and complex data types

- gold Open Access which fosters wider collaboration and increased citations

- maximum visibility for your research: over $100 \mathrm{M}$ website views per year

At $\mathrm{BMC}$, research is always in progress.

Learn more biomedcentral.com/submissions 